\title{
Naturalistic Values and Progressive Politics
}

A Missing Link Between Pragmatism and Social Theory

\section{Christoph Henning}

\section{(2) OpenEdition}

Electronic version

URL: http://journals.openedition.org/ejpap/770

DOI: $10.4000 /$ ejpap.770

ISSN: 2036-4091

\section{Publisher}

Associazione Pragma

Electronic reference

Christoph Henning, "Naturalistic Values and Progressive Politics », European Journal of Pragmatism and American Philosophy [Online], IV - 1 | 2012, Online since 23 July 2012, connection on 19 April 2019 URL : http://journals.openedition.org/ejpap/770 ; DOI : 10.4000/ejpap.770

This text was automatically generated on 19 April 2019.

\section{c) $(1) \odot$}

Author retains copyright and grants the European Journal of Pragmatism and American Philosophy right of first publication with the work simultaneously licensed under a Creative Commons AttributionNonCommercial-NoDerivatives 4.0 International License. 


\title{
Naturalistic Values and Progressive Politics
}

\author{
A Missing Link Between Pragmatism and Social Theory \\ Christoph Henning
}

\section{What is Sociological Pragmatism?}

1 In 1921, major contributions of the Chicago School of Sociology had already appeared. ${ }^{1}$ Nevertheless, in the same year Charles Horton Cooley noted in his Journal: "A social, or perhaps I should say, a sociological pragmatism remains to be worked out." ${ }^{2}$ This seems to be a strange judgment: Not only is Cooley himself often considered both a sociologist and a pragmatist who, as a father of the interactionist paradigm, is mentioned together with G. H. Mead and John Dewey (Schubert 1995). There is also an understanding that the Chicago School was strongly influenced by the pragmatist philosophers and psychologists Dewey (who taught in Chicago from 1894 to 1905) and Mead (who came with Dewey and taught there until his death in 1931). Burgess and Park 1921, for example, extensively quoted Dewey in their influential work; others like Charles Ellwood (1873-1946) were even Dewey's direct students. ${ }^{3}$ So what could this odd statement mean?

2 A closer look at the context reveals that Cooley attributed this to William James's Psychology (1890). What Cooley missed in James was this: "he saw men as separate individuals." Now one may wonder, how else should we look at 'men'? To understand Cooley right, we have to consider his own ideas: "Although William James had insight into the social nature of the self he did not develop this into a really organistic conception of the relation of the individual to the social whole." ${ }^{4}$ So it is not enough to consider the "social nature" of individual selves, which I would here interpret as a social origin or prosocial attitudes (that is: a genetic or ethical claim). Cooley was after an ontological claim: an organistic theory, which understood individual and society not as separate entities, but - in a quest for unity reminding of Hegel and Dewey - as two 'poles' of a larger whole. European 19th century organicism had already developed similar ideas, with Spencer and Schaeffle being just the tip of the iceberg. However, whether these theories were 
"sociology," or rather a speculative metaphysics of society which the emerging science of sociology needed to overcome, this question was subject to heated debates (Small 1916, Salomon 1926).

Cooley himself had developed a weakly organicist view almost 20 years earlier, holding that "society and individual denote not separable phenomena but different aspects of the same thing" (Cooley 1902: 37). So the sociological theory he asked for was there already. This, however, can only mean that in this quote he did not consider his own writings pragmatist. That leaves us with an unagitated reading of Cooley's quote: since he did not consider himself a pragmatist here, his own writings did not count. And since many sociologists were skeptic about organicist metaphysics of society, this does not tell us much about sociological pragmatism. Just as stated before, the Chicago school could still be counted as a qualified candidate for a 'sociological pragmatism,' even if Cooley himself did not see one around.

4 In a classic paper, Hans Joas thought otherwise. He reads this quote as evidence that certain elements of the pragmatist philosophy had not been properly 'translated' into sociological theory. Interestingly, he extends this claim not only to Cooley (Joas 1992: 33), but also to the cherished G. H. Mead (Joas 1992: 35), and even to 'the' Chicago sociologist, Robert E.Park: "it can not be claimed that Park and his students succeeded in transforming pragmatism into a satisfactory theory of society" (Joas 1992: 48). Now, this leads to a peculiar situation: it almost looks like a game of naming and shaming, where the accusation to be 'not social (or sociological) enough' can be passed on forever: Cooley claimed it about James (and Spencer); Mead 1930 claimed it about Cooley, now Joas claims it about Mead and Park. ${ }^{5}$ (Ironically, today one might say this about Joas, who now has become a philosophical and religious writer.) So again we have to ask what this accusation could mean.

Where 'sociology' designates an empirical science, based on a reliable theory of modern society, the accusation can either mean that said authors were not sociological enough. This is the case when Joas criticizes Mead: his "ideal of democratic self-government [...] is not used to elaborate a theory of society that could also be put to sociological use" (Joas 1992: 35; "use" I here take to mean: used as a theoretical guide for empirical research). The same interpretation is at work where Joas compares W. I. Thomas' theories not to sociology, but to "humanistic psychology" (Joas 1992: 43; like Karen Horney, Erich Fromm or Abraham Maslow). Likewise, he claims that Park and his students had nothing to say about class, bureaucracy or international relations (Joas 1992: 48). But the accusation can also mean something else: Since we are looking for a sociological pragmatism, it can also mean that a certain sociology is not pragmatic enough. We find this understanding in Joas' text, too; for example when he criticizes Cooley for relying on emotions instead of actions (Joas 1992: 33); or when Mead is accused of becoming an "utopist" (Joas 1980: 207; see below).

6 This leaves us with a dilemma: If we are looking for sociological pragmatism where we expect to find it: in American academia of the 1920s, we find sociology as well as pragmatism. But we also perceive a gap between them. It seems to be difficult to find a proper "sociological pragmatism." However, this problem only arises from a certain perspective: Only if we look at sociology and pragmatism as two unrelated things we have to search for a link in order to build a synthesis. But this narrow focus is not necessary. Once the perspective is broadened a little, they appear as two branches of the same tree. Then we no longer have to 'construct' a link, for the two branches are linked already. To 
cut a long story short, the larger stream that carried them both was the progressivist movement.

\section{Progressive Politics in Pragmatism and Early Sociology}

7 A History of Sociology from 1948 distinguishes two different "sociologies" throughout the history of the discipline:

Comte, Morgan, and Ward believing that the main purpose of sociology is to facilitate planned progress, while Spencer, Sumner, and Gumplowicz held that the great practical service of sociology is to warn against the futility and danger of the notion that man can facilitate and hasten social progress through deliberate action.

(Barnes 1948: ix)

8 A similar distinction between proactive and cautionary social theory could be made between Max Weber, who rejected value judgements in sociology, and 'valuing' sociologists like Franz Oppenheimer; between self-proclaimed 'critical' theorists in the wake of Max Horkheimer and positivists following Karl Popper; and even the debate between Jürgen Habermas and Niklas Luhmann in the 1970s could be framed this way. One party is in favor of progress; the other one is not against it, but only against planned progress, for such a planning could prove wrong-headed or illiberal. Their position rather is that progress is happening anyway ("naturally," as an evolution), so it is not for citizens or sociologists to decide which direction it should take.

Now, it is important to see that the aim to facilitate and direct progress was exactly the program of the progressivist movement in the USA. As a political movement, it is usually dated from 1890-1921 (Allerfeldt 2007). As an intellectual movement, however, it started earlier, with Henry George's Progress and Poverty, written in 1879, being a landmark publication to stir the debate. By the late 1870s, the United States witnessed rapid and tremendous changes. But whether this was a "progress" was an open question. With industrialization came inequality and poverty, and with urbanization came a growing anonymity and a sense of alienation (Sandel 1996: 201ff.). From the beginning the debate had a clear economic focus - more precisely, it was clear regarding the criticism of the "rugged individualism" of the Gilded Age, but not so clear about the alternatives. Henry Carter Adams, Richard T. Ely and John Bates Clark (soon to be called the "ethical economists") were contributing to an economic critique of unfettered capitalism by the mid-1880s already. But as liberal economists they were torn between full blown socialism and traditional market liberalism. ${ }^{6}$ In the 1930s John Dewey still tried to find some via media (LW 11; cf. Kloppenberg 1986): even though he was in favor of "industrial democracy" as early as $1888,{ }^{7}$ he rejected efforts of his scholars Max Eastman and Sidney Hook to draw him towards Marxism or Trotzkyism (Phelps 1997: 55ff., 148ff.). To be progressive meant to be in-between, even if it was not immediately clear what that meant concretely.

10 Likewise, the emergence of American Sociology since the 1880ies was motivated by a need, deeply felt by many, to 'do' something about the social disturbances which accompanied the rapid industrialization and urbanization. It did not necessarily mean that progress needed to be made. Progress was manifest anyway. What it meant was that the socio-economic and cultural changes needed to be directed into a "desirable" direction (to use Dewey's moral term). Using a language of fields inspired by Pierre Bourdieu, one 
might say that the (economic) liberalism early American Sociologists attacked was neither the emerging large-scale capitalism directly, nor its justification in the new economic theory (the marginal revolution was only just underway). Rather, they had the sociological version in mind which dominated the sociological field of this period: the theories of Herbert Spencer and their American complement, William Graham Sumner. ${ }^{8}$ In a Nietzschean move worthy of later liberals like Hayek, Sumner had radically ruled out any third-wayism:

Let it be understood that we cannot go outside of this alternative: liberty, inequality, survival of the fittest; not-liberty, equality, survival of the unfittest. The former carries society forward and favors all its best members; the latter carries society downwards and favors all its worst members. (Summer 1914: 25)

This theory posed the following difficulty: if capitalism would have been pictured as one 'culture' amongst others (which seemed possible, given that the changes were quite recent) it would have been easy to beg to differ. However, this was not the way the debate was framed. Rather, capitalism was perceived as a 'natural' thing to have, since it was based on nature. Sumner wrote in 1883 already:

Certain ills belong to the hardship of human life. They are natural. They are part of the struggle with Nature for existence. We can not blame our fellow-men for our share of these. My neighbor and I are both struggling to free ourselves from these ills. The fact that my neighbor has succeeded in this struggle better than I constitutes no grievance for me. (Sumner 1883: 17f.)

Once this underlying socio-natural philosophy was hegemonic, this claim could be made in a 'neutralist' scientific fashion that was not open to debate. You cannot argue with natural forces, as German Neo-Kantian Rudolf Stammler (1896: 430ff.) had insisted against socialism. (Confronted with this 'naturalizing' power of ideological discourse theories of social and participatory democracy still look week today.)

In this situation, the progressivist agenda to 'do' something about the situation was facing a dead end. of course, proponents of reform could try to bring their voice out into the public - and for years Robert E. Park did just that when he worked as a journalist. (At one point he planned a weekly magazine with John Dewey in order to inform the public better. $)^{9}$ However, as long as demands for, say, more real freedom and equality appeared as efforts to argue with 'nature,' this had a similar effect as barking at the moon had none. So in order to be heard, the naturalistic hegemony of "laissez-faire" liberalism needed to be broken first. Karl Marx tried to do this in his economic writings for Europe. This is also what early American Sociologists set out to do. Frank Lester Wards Dynamic Sociology (published 1883, the year Marx died) was attacking the laissez-faire school head on, too. ${ }^{10}$

The clue to this effort, however, was that it had to start with nature (just like Marx had done in his German Ideology, Henning 2009). This was not just a matter of taste of authors like Ward or Thomas who happened to be interested in biology and botanics. Dewey spelled out the dilemma most clearly. If nature was left aside and progressive theory jumped to a normative view of society immediately, this remained pure articulation of subjective taste without any moral force:

There will be one philosophy, a realistic one, for mathematics, physical science and the established social order; another, and opposed philosophy for the affairs of personal life. [...] But philosophical dualism is but a formulated recognition of an impassé in life; an impotence in interaction, inability to make effective transition, limitation of power to regulate. (LW 1: 186) 

then arguments from an analysis of society could no longer be neglected with recourse to nature. They had to be taken seriously. This explains why social sciences were crucial to the progressive movement; a "The Reconstruction of Society by Social Science" was needed (Barnes 1948: 173ff.). But it had to be a social science that could explain itself over and against the dominance of the natural sciences and naturalistic ideologies. For this reason the botanist Ward was extremely important for the birth of progressive sociology: his attack on the laissez-faire doctrine (Ward 1883 I: 31ff.) was no naïve Social Gospel or remote moralism. It was based on a firm philosophy of nature, which was as informed about Darwin as Sumner was.

is no coincidence, then, that Wright-Mills' early search for the link between Sociology and Pragmatism perceived a "tradition from Ward, through Dewey, to W. I. Thomas and Mead" (Wright Mills 1964: 448; written 1941). "Many passages of this book [Ward 1883] could almost have been written by John Dewey" (Wright Mills 1964: 462). I agree. What allowed for this continuity not only between nature and society, but also between Ward and Dewey - and that is: between early Sociology and Pragmatism?

It begins with a similar philosophy of science. Science needed to prove itself for practical purposes, or it was pointless. Describing a similar dualism between a meaningless natural science and subjective moral judgments, Ward (who quoted Peirce in this work already) wrote 42 years before Dewey:

The real object of science is to benefit man. A science which fails to do this, however agreeable its study, is lifeless. Sociology, which of all sciences should benefit man most, is in danger of falling into the class of polite amusements, or dead sciences. (Ward 1883: xxvii)

As we saw, sociology did not just aim at a random benefit, but at a planned social progress (Wards sociocraty: "the rule of society by society"). ${ }^{11}$ How did Ward prove it was possible? His main argument was that the "statical" perspective taken in biological theory and sociology was not enough. Sociology needed to take "dynamical action" into account: "it is not what men are, but what they do" (Ward 1903: 15). The following passage foreshadows Dewey's distinction between "habit" and action guided by "intelligence":

Dynamical actions are distinguished from statical actions in proceeding according to the indirect, or intellectual, method of conation instead of the direct, or physical, method. [...] In statical actions the movements of the agent are made in straight lines toward the end. In dynamical actions, they are not so made, but may proceed in any other direction. (Ward 1883 II: 378)

Dynamic action was defined by a conscious purpose. Now, if individuals may define and pursue a purpose, then societies should be able to do this, too. At least in Europe they did, by developing social insurances, a welfare state and municipal services, for example. Experiencing this European 'progress' was crucial for progressive writers, many of whom had studied in Germany. Mead, e.g., was deeply impressed "how cities sweep their streets, manage their gas works and street cars, their Turnvereins" etc. ${ }^{12}$ Being able to set a purpose both individually and collectively ("collective telesis," Ward 1898: 260ff.) distinguished humans from other natural beings. But then doing this no longer is a mistake. It does not mean to mess with mother nature if setting collective purposes is our very nature.

Saying this with scientific intent, however, leads to the question which the purposes in question are. Nature can be studied. Even if there is a difference between humans and 
(other) animals, we should be able to say more at this crucial step. Indeed, Ward had an idea here: he suggested to use human emotions as a key: "What function is to biology, feeling is to sociology" (Ward 1883 II: 123). Feelings are particularly human. At the same time they are natural enough to be a "force" in human conduct. Hence, Ward called them "social forces" (1883 I: 480ff.). One of them - the notion of "sympathy" which already appeared in Adam Smith - made a special 'career' in later progressive writings: "Reform should be based on Sympathy" (Cooley 1909: 13f.). ${ }^{13}$ This sociology believed it could define naturalistic values in order to direct the social progress. "Today men think for a purpose. The purpose is one: the elevation of men" (Ward 1883 II: 123). Or, with Dewey (1920: 141): "Growth itself is the only moral 'end'."

This idea of naturalistic values defined by social forces was handed on to other sociologists. ${ }^{14}$ It is still visible in the writings of Albion Small (1854-1926), progressivist and institutional father of the Chicago School. Small saw an "impulse to improve ways of improving the world" incorporated in sociology (1916: 828). As early as 1893 (according to Barnes 1948: 782) he formulated his objective list of human interests: "health, wealth, sociability, knowledge, beauty, and rightness," which he deduced from basic emotions (Small 1905: 196, 682). ${ }^{15}$ Interestingly, Small quoted Dewey for these interests (Small 1905: 433). And like Ward, Small perceived that there was evolutionary progress in society anyway ("Natural life is conflict, but it is conflict converging toward minimum conflict and maximum co-operation and sociability," Small 1905: 371). This progress needed conscious planning and direction, which made it the aim of sociology to provide the proper ends or values. Considering the methodic question how such naturalistic values might be discovered, Small - who is often described as a minor theorist - was influenced by Peirce, foreshadowing K. O. Apel's and Habermas's writings of the 1960s:

The most reliable criterion of human values which science can propose would be the consensus of councils of scientists representing the largest possible variety of human interests, and co-operating to reduce their special judgments to a scale which would render their due to each of the interests in the total calculation. This declaration of principles [...] would not be the abdication of science. It would be science with stripped of cant. [...] It would be science with its decks cleared for action. (Small 1910: 260)

Even if this sounds like the technocratic elitism later developed by Walter Lippmann and others, this was not the issue for Ward and Small. They rather asked for public discussion of societal issues, based on the best knowledge available. Hence the need for a functioning media, which was so important to Park and Dewey. Hence, also, the stress on education. It became an eminent political end (in-view or not) to provide good education for everybody. Dewey and Tufts called this "equality of opportunity," Ward even more pointedly "intellectual egalitarianism" (MW 5: 490 f.). ${ }^{16}$

The idea of the social forces moved even further, from Ward to Small, and from Small to W.I. Thomas (1863-1947). In his terminology "four fundamental wishes" remained (Thomas 1921: 27): the desire for new experience, ${ }^{17}$ for security, for response (or affection by members of the in-group) and for recognition (distinction, or a certain status within the larger group). This anthropological base - which was later modified, but never given up completely ${ }^{18}$ - was sometimes criticized as un-sociological. Wrongly, I think: Its function was not to put empirical investigations aside by 'deducing' something from a fixed concept of nature as "supreme reality" (MW 12: 92). Social sciences do not have to assume that humans can do without nature (that would be an absurd claim). To the contrary, an anthropological base allowed for a better sociology. It served two purposes: 
First, in order to compare different cultures or their mutual impact, what the Polish Peasant (Thomas \& Znaniecki 1918-20) did masterfully, one has to know what is to be compared in the first place. In order to understand local differences or historical changes, something needs to be fixed (a tertium comparationis). Otherwise we would only see drift and fluidity, which teaches us nothing:

What distinguishes societies and individuals is the predominance of certain attitudes over others, and this predominance depends, as we shall see below, on the type of organization which the group has developed to regulate the expression of the wishes of its members. [...] We can, therefore, gain a better understanding of the heritages of the immigrant groups [...] by examining briefly the nature of the human wishes and the form of the social organization which control the wishes of our immigrants at home. (Thomas 1921: 25f.)

24 So considering these fundamental wishes allows for better comparisons. And what is more, they also carry a (weak) normativity. They often are "repressed" to a great extend (Thomas 1951: 117, written 1918), but they should not be repressed altogether: "We may assume also that an individual life cannot be called normal in which all the four types of wishes are not satisfied in some measure and in some form" (Thomas 1951: 144, written 1925). Thomas and Znaniecky had a 'pragmatic' understanding of values which bound together objective (social) values and subjective valuations (attitudes) in a larger practical unity. To quote the 'famous' phrase from the Polish Peasant: "The attitude is thus the individual counterpart of the social value; activity, in whatever form, is the bond between them" (Thomas 1951: 50, written 1918). Those actions are neither embedded in a transcendent set of objective value, nor in a transcendental set of subjective attitudes (in Deweyan terms, they do not presuppose "fixed ends"), but in a "situation" in which values and attitudes come together. "Every concrete activity is the solution of a situation" (Thomas 1951: 57). So in order to understand human action, we need to understand the situation. And consequently, in order to bring about "progress" in the course of action, the situation needs to be changed - which includes the environment as well as attitudes.

Obviously this situationist approach is very close to Dewey's take on ethics. This parallel has three aspects: methodological, concerning the material, and in regard to "progressivist" conclusions:

26 - First, in the general understanding of morality Dewey replaced what seemed to him "a single, fixed and final goal" in traditional theories with "individualized goods and ends" which depended on the situation. This way, "every moral situation is a unique situation" (MW 12: 173). In order to understand the moral dimension of an act, we need to understand the concrete situation first, withholding the inclination to subsume it under general principles to quickly (Dewey \& Tuft 1908: 197ff.).

27 - Secondly, this level of concretion did not lead Dewey to give up ethical theory (a possible conclusion if only "changing, moving, individualized goods" remain, 132). Instead, his ethics exemplarily analyzed the general "situation" of the United States in 1908 and again in 1932. In a good progressivist fashion Dewey and Tufts (MW 5: 457) primarily describe the "economic situation." Ironically, the most concrete level of analysis Dewey ever got to in terms of social theory was in ethics.

28 - Thirdly, the normative conclusions drawn do not refer to the morality of individuals (as in Victorian efforts to legislate morality), but to the social conditions. For example, Dewey and Tufts (MW 5: 390ff., 470ff.) elaborated the notion of "effective freedom" and "equality of opportunity" which were already common in the progressivist literature. ${ }^{19}$ 
Comparable to Thomas' logic of the situation, it included both: working on external (e.g., freedom from want) as on internal conditions (e.g, freedom from fear).

These two schools of thought, pragmatism and the Chicago School of Sociology, found a way to escape the accusation of a naturalistic fallacy (Bohmann 2010). Unfortunately, though, both poles of the "naturalistic values" - nature and value - become increasingly difficult to articulate in the process of professionalization of a social science. Values become the object of social science the more it is confronted with pluralism (a parallel to Max Weber in European sociology). To pursue one against the others would be partial and naïve. Hence, Park believed that "a moral man cannot be a sociologist" (cited in Lindner 2000: 217). However, as long as sociology claims to be a progressive force in society, it must enable others to make better value judgments. And even Park "saw sociology as ultimately useful and practical":

Applied sociology is not concerned with uncovering mechanisms and devices for reform, but with exposing the broad setting of social organization and human nature which policy-makers must take into account. (Turner in Park 1967: xvi)

Sometimes sociology may even articulate new and more reflective values itself. One biographer of Park describes his ideal, which resembles Simmel and Habermas' Peirceian normative social philosophy, the following way:

the task of communication [...] becomes a cultural ideal which transcends traditional bonds, in order to arrive at a common universe of discourse. [...] Communication enables individual experiences to be integrated, but not sublated. (Lindner 1996: 112; cf. Lindner 2000: 225)

Consequently, human nature is not simply a "given" which may be stored in a scientific box. In the 1920s this was shown by the critique of instinct psychology by Faris (1921), a Chicago scholar, and Bernard (1924). ${ }^{20}$ Nevertheless, the concepts of nature and "human nature" remained crucial ones, in both pragmatism and Chicago sociology. As Mead had anchored his symbolic interactionism in an organic perspective and Dewey (MW 14) developed an anthropology of habit and impulse, Park (1915: 583) held that the study of the city would "reveal to us human behavior and human nature generally." Later studies relied on a "biotic" vocabulary even stronger (Park et al. 1925), laying foundations for the discipline of 'social ecology.'

Systematically, therefore, these underlying naturalistic values do not mark the difference between pragmatism and Chicago Sociology. They can be found in both branches of the progressive tree. Before I elaborate where a crucial difference between them lies which is often overlooked in the literature, I would like to elaborate in some detail how Dewey, the most systematic of the progressive thinkers, explained naturalistic values. He was quite aware of the criticism of naïve conceptions of human nature and values. Nevertheless he spelled out a normative anthropology himself.

\section{John Dewey on Naturalistic Values}

European sociology could not easily 'digest' the evaluative approach in social theory (Tenbruck 1985). The reason was epistemological: The fact-value distinction was very relevant in a European Kantian framework. However, since American progressivists were influenced more by Hume and Darwin than by Kant, they were less concerned about normative 'valuing' in science. ${ }^{21}$ This motivates a deeper look into the normative implications of the naturalism typical for progressive thought from Ward to Dewey and 
Park. Clearly, their naturalism was not reductionist (Bohman 2010, Gale 2010). They did not try to belittle the impact of culture and history, or even of mind and free will ("intelligence," in Dewey's terms). Rather, they looked at the way their nature allowed human beings to act and interact in different ways, creatively changing their natural and social environment where possible. As we have seen in Ward and others, starting with a natural perspective does not preclude arriving at social or cultural phenomena. Rather, this avoids the "dualism" described by Dewey which would make these theories vulnerable to a criticism from the hegemonic laissez-faire naturalism.

Dewey was highly critical of two different ways of thinking: as we have seen, one was the ideological liberalism which was based on an abstract individualism. The other one was traditionalism, based on a rigid intersubjectivism. (Both are still with us today.) Both of them tell stories about foundations: the first one disembedds the atomistic individual from its social settings and remodels everything in its image. Even if the model aims to be purely formal, it is still based on a particular conception of the individual: a market-type consumer who 'chooses' norms according do his interests (MW 5: 77, 478). The second model relinquishes individuals to the social powers around them (families, tribes, local customs etc.). This social constructivism implies an ontological claim about the foundation of norms in certain social communities. Ironically, today it is particularly popular with readers of Mead like Habermas, Joas or Honneth. But if normative claims are only (quasi-)based on local habits ("folkways," Sumner 1907), on the way we do it, this has very limited normative power in different contexts with different local habits. Neither is it a promising prospect for a deeper and non-conformist individualism, as it was one of Dewey's main aims.

Here is the dilemma Dewey faced: basing norms on an abstracted concept of the marketindividual ("liberty") is ideological and over-abstract; whereas an ethics based on the selfconception of pre-industrial white middle-class Mid-west American town-life ("community") is limited to this particular context. Basing ethics on the individual or the social life may therefore both be dead ends, at least for progressivists. But not basing them on anything is not a way out, either, for that would leave it adrift in practice, and prey to whatever ideology comes around in theory. So where do we go from here?

Dewey criticism of both theories is based on human nature. Even though both theories claim to represent human nature, neither of them is reaching down to it. Any particular community is historically and geographically contingent, and so is "rugged individualism": it is an abstractification of another section of the same community - the role taken in economic transactions (at least in their textbook representation). Both claims are taken for granted (as natural) by their followers, yet they only represent contingent and particular facts which are open to change. Consequently they can not be legitimized with reference to human nature. Saying so, however, presupposes that there is something like human nature we may refer to. (To see this, note that in order to say 'a is not an $\mathrm{x}$,' we need to know first what the characteristics of $\mathrm{x}$ are.)

Today many philosophers and social scientists abhor naturalist claims (Pinkert 2002), for all too often they petrify contingent facts and try to end all discussion. However, for Dewey this was different. If Dewey's main interest, which attracted him to Hegel, was the overcoming of dualism, then the dualisms of body and mind, or nature and culture, are among the most important ones. For Dewey being at home in the world also implies to be at home in one's nature, both as an individual (Dewey was a nonconformist) and, more generally, as a natural being. So we should expect a more positive approach towards 
human nature then the neo-pragmatist allows for. ${ }^{22}$ Indeed, Dewey describes human nature as "raw materials" (MW 14: 78) that can take different shapes. It is cultivated in many different ways, with habits as a second nature guiding most of our actions. These habits are contingent and forever changing. Consequently this conception can not prescribe a certain way of being, like theories of natural law used to do. Dewey does not even try to define a fixed set of instincts, for even they may change (MW 14: 144). This concept of human nature is quite liberal. In an ingenious reversal, Dewey claims that illiberal consequences rather have to be feared if we base our norms on culture and tradition:

As a matter of fact, it is precisely custom which has the greatest inertia, which is least susceptible of alteration; while instincts are most readily modifiable through use, most subjective to educative direction. (MW 14: 76 f.)

Even if this is so, taking humans 'first nature' (as I call it, Henning 2009) into account is not morally empty. The biotic base, which is always present in action, is both an enabling condition and a limit: "The natural, or native, powers furnish the initiating and limiting forces in all education; they do not furnish its ends or aims" (MW 9: 121). The short title for this dimension in Dewey's thought is "impulse." To a certain extent, it reflects Mead's concept of the "I," which transcends the socialized roles a person can "take over" in so far as it is the organic source of motivation ("The 'I' is the response of the organism to the attitudes of the others," Mead 1934: 175). As a source of motivation, it is also a source for creativity and values:

The possibilities in our nature [...] are possibilities of the self that lie beyond our own immediate presentation [...] It is there that novelty arises and it is there that our most important values are located. (Mead 1934: 204)

Two non-redundant aspects need to be considered here: First, if all the different cultures emerge from the same human nature, we have something in all plurality and difference that unites us. Every human being is equal in this respect. We all share this common organic nature, this humanity. For Dewey this common nature is best understood as a human perfectibility: "Not perfection as a final goal, but the ever enduring process of perfecting, maturing, refining is the aim in living" (MW 12: 181; hence the desire for growth without "fixed ends," MW 14: 159). Everybody can do this and is doing this in fact (remember Thomas' fundamental wish for new experience). Without this shared human nature, claims for equal respect, equal dignity etc. would not make much sense. They would be 'unfounded.'

The second normative aspect is dignity: Human nature has a certain normative power because it is so fragile. Cultural forms and types of subjectivity develop from this base, but they may also squeeze this potentiality or pose obstacles to our "growth." Here this anthropology strongly relates to social theory. If we can not develop ourselves, both individually and culturally, human nature will sooner or later revolt:

At critical moments of unusual stimuli the emotional outbreak and rush of instincts dominating all activity show how superficial is the modification which a rigid habit has been able to effect. (MW 14: 72)

41 Now, if under certain circumstances such outbreaks of emotions have to be considered natural, but this "natural" dimension is the source of value, people should be given a right to behave in this way. ${ }^{23}$ Thus, freedom is founded upon our first nature: "impulse is a source, an indispensable source, of liberation" (MW 14: 75). Hence, protecting this universal human nature by moral and legal norms is protecting cultures as well as individuals. It is well founded, and it also includes both, liberalism as well as 
communitarianism. Moreover, it is even cosmopolitan: Protecting this "nature of freedom" ( 8 ; vgl. 306) is protecting a fundamental human potential that can be found in every culture. In short, this theory is not redundant because it does not permit everything: as soon as a certain culture (a rigid habit) starts to curtail the development of its own people, they have a good reason to oppose this from their own context. Then, we have a reason to share their concerns because our common nature makes us natural allies in this respect. ${ }^{24}$

Against the strong intersubjectivist who may claim with Mead (1934: 167) that the "only way in which we can react against the disapproval of the entire community is by setting up a higher sort of community," it is only part of the story that this would be "the voice of reason" (ibid.: 168). It would also be the voice of our nature, which is an even stronger one. There is not only one "reason," as Isaiah Berlin has rightly stressed (especially if we bind reason to situations, as Dewey and Thomas did). But there is only one human nature. "Ethics is a part of our nature and needs no justification" (Gale 2010: 73). This is why the old Dewey could still say:

naturalism finds the values in question, the worth and dignity of men and women, founded in human nature itself, in the connections, actual and potential, of human beings with one another in their natural social relationships. (LW 15: 54)

So for Dewey, the voices of reason and nature are not so far apart at all: In a dialectical move almost resembling Schelling, Dewey speaks of a "stimulation of reflective imagination by impulse" (MW 14: 121). We only get to intelligence through impulse: if habits face an "interruption" or "disturbance" (MW 14: 125), impulses are set free and call for a new direction. So reason ("an effective relationship among desires, rather than a thing opposed to desire," MW 14:135) is firmly based in nature. But this is a nature that is not coextensive with what natural sciences say about it.

Even if it may lead us astray, to underpin this point here is another, even more striking reminiscence to Schelling. It comes up when Dewey describes a feeling of unity between nature and reason in artistic activity:

In creative production, the external and physical world [...] is subject-matter and sustainer of conscious activity; and thereby exhibits [...] the fact that consciousness is [...] the manifest quality of existence when nature is most free and most active. (LW 1: 293)

This indicates that for Dewey not only moral values are deeply rooted in our (first) nature. We touch the same sphere in aesthetic experiences; a trait that connects Dewey with Adorno. Having mentioned Adorno, let me now come back to the issue of sociology.

\section{Another Gap Between Pragmatism and Sociology}

So far I have shown that there are several traits shared by pragmatism and the Chicago school of sociology, which have a common source in the progressive movement. The progressivist creed was based on notions of sympathy (as opposed to "atomism"), the common good (as opposed to individual desires) and the "social self" (as opposed to egoism). It strongly linked theory to an ameliorative practice, and reconstructed theory in order to reconstruct society. Normatively this new theory was founded on naturalistic values. These points were elaborated by sociologists like Ward, Small or Park as well as by Pragmatists such as Mead or Dewey. With the continuous topics came a shared methodology: these middle range theories no longer searched for general theories or 
fixed ends. They constrained themselves to analyze concrete situations, helping to find means for the ends-in-view. In these "situations" and corresponding activities, objective and subjective factors were bound together. Therefore, explanations could not be had by a reduction to either subjective (psychological) or objective (structural) factors alone.

In all of this, no clear "gap" has yet appeared between sociology and pragmatism. Does this mean that Joas' and Cooley's assumption was wrong? Yes and no: He was right in noting a gap. I beg to differ, however, in the way this gap is described. With Joas' rigid criterion in mind, hardly any author would count as a sociologist; at least not the authors using the "renaissance" of pragmatism for social theory, like Habermas, Honneth, or Joas himself: they neither undertake empirical research, nor do they have much to say on issues of class conflict or international politics..$^{25}$ As we have seen, this could even be said about the Chicago sociologists. So instead of explaining the gap, this criterion only mentions another commonality.

But there is a gap nevertheless. This gap has to do with two of the common themes: the social self, and naturalistic values. As will be seen, they are interrelated. Counterintuitively, the more we allow for nature, the more individualism we allow, whereas a stress on sociality transports conformist ideas. In terms of nature the difference may be described thus: There are two ways in which values can be naturalized: either we project mind back into matter, or we follow nature reaching into the minds. Either way, we overcome dualism and get a higher 'unity.' However, these are two different 'wholes': in Schellings terms, one is a subjective subject-object, the other one an objective subject-object. Likewise, Marxists distinguished between idealist syntheses and materialist ones. This seems to be philosophical hairsplitting, but following the pragmatic maxim to look for practical consequences, it makes a tremendous difference in practice. The first is moralizing nature, the second is naturalizing morals.

This, finally, is a real difference between the two schools: In spite of all its criticism (cf. LW 1: 295 ff.), pragmatism always remained a philosophy; whereas sociology left behind its speculative phase and professionalized itself into science. As philosophy, pragmatism was inclined to solve problems on the conceptual level already. However, if a problem disappears conceptually, we may no longer perceive it in reality (whereas perceiving problems is the main job of empirical sociology). To us, it will rather seem as a "mistake" or false consciousness in those who claim there is a problem. Imputing mind into matter, or morals into nature, is doing just this: once accomplished, there no longer is a conflict, if only we perceive the world the right way (the only problem left is how to educate the other people, which was one of Dewey's main aims).

It is not a new approach to interpret Dewey as an idealist who spiritualized nature, so I can be brief here. Scholars have shown that Dewey kept his spiritualist beginnings all his life, transforming it into a language in line with scientific modernism, but maintaining that "mind is implicitly present in matter" (Gale 2010: 66). As Andrew Feffer has argued, it survived a reshaping into empirical psychology, as visible in the well-known essay on the reflex-arc from 1896:

As in his earlier expositions on the New Psychology, in his reflex-arc article Dewey sought to demonstrate, incontrovertibly and scientifically, the thoroughgoing immanence of mind in the neurological functioning of the body and the presence of telos in the biological functions of human existence. (Feffer 1993: 148f.) ${ }^{26}$

But this continuity is not limited to the early Dewey. It was made to last: 
When Dewey made the transition from absolute idealism to what he called alternatively pragmatism, instrumentalism, or experimentalism he merely changed the name of this background unity from 'universal consciousness' to experience, this being a case of pouring old wine into new bottles. (Gale 2010: 60f.)

Richard Gale claims that especially the later terminology of experiments and "experience" carried a 'unitarian' and mystical philosophy: ${ }^{27}$

The reason why no one ever understood what Dewey meant by 'experience' is not because he was a poor writer, as is commonly claimed, but rather because he was formulating a mystical doctrine. (Gale 2010: 62)

Now, if nature is tamed conceptually, there is nothing to fear from it. As a force (to cite Wards) it no longer is 'alien.' This is certainly a good thing for individuals - in spite of his reservations to psychoanalysis, Dewey is quite close to positive psychology here. However, when it comes to social matters, there is a danger of abstracting away the crucial conflicts that arise in and from nature. Yes, the struggle for life Darwin had focused on ("eat or be eaten") became an ideology when everything social was read in its image. But it also referred to something quite real in nature itself. For authors following the other path of combining nature and values, this meant that even in society there were 'natural' conflicts (over territory, food, mates, access etc.). For example, when Ward (or Marx) pointed to cut-throat-competition on the market or Park to the biotic processes in the city, ideology would consist in not seeing this.

Read in this way, the accusation cited above - not to be social enough - acquires a whole different undertone. No longer it means that the criticized author is not sociologist (that is: empirical) enough. Rather, it is a conceptual accusation, implying that there is too much of a dualism at work: as long as there is antagonism, or even a duality of nature and culture, the theory is said to be 'not social enough.' (Remember that this is what Cooley said about James, Mead about Cooley, Joas about Mead, and Schubert about Park - the list could go on.) But then, being 'social enough' only means to claim that conceptually everything is social through and through (or, in Germanic terms, intersubjectively constituted'). This, however, is not a sociological position, it is metaphysics. Pragmatistic philosophers complain about sociologists who still work with a conflict between nature and culture. Ward, for example, argued that "natural forces" like competition were still powerful in society, so "social forces" needed to counteract them:

All human institutions - religion, government, law, marriage, custom - [...] are, broadly viewed, only so many ways of meeting and checkmating the principle of competition as it manifests itself in society. (Ward 1893: 262)

In a review of Ward, Dewey argued against the "sharp break between culture and nature" which he attributed to a conceptual mistake (Dewey 1894: 201ff., cf. Rafferty 2003: 107). Park, to give another example, believed that we can not simply assume that people will cooperate, just because "cooperation" is in some way also natural. As an empirical scientist, he had to concede that in real cases competition often came first, and very powerfully. It needed a lot of energy in order to (successively) arrive at conflict, accommodation, or "assimilation" (acculturation). ${ }^{28}$ He even spoke of a "natural history" here (Coser 1971: 362). ${ }^{29}$ However, philosophers of intersubjectivity later complained that this is a conceptual "dualism" (Schubert 2010: 91f.; cf. Joas 1992: 47f., Lindner 2000: 223f.). I would like to defend the sociological scholars against this Hegelian pressure to achieve reconciliation at a conceptual level already. If the problem is real, we only achieve progress if we acknowledge the problem first, and as clearly as possible. Otherwise, if our 
theory is seeking harmony from the start, we end up criticizing the critics instead of the problem.

This difference in locating nature theoretically also has an important impact on the range of individuality a theory can afford. In the second - sociological - interpretation where nature extends into society, we have a clear view on the Hobbesian dimension in society (without necessarily totalizing it, which would lead to Sumners laissez-fairism). As we saw, this creates some philosophical discomfort, since conceptual unity can not be achieved so easily. However, for the image of the individual this means that he or she is never fully under "social control." Apart from all their entanglements with society, they remain an autonomous actor, a potential troublemaker - a nonconformist who is able to use his different roles ("masks") strategically. This qualitative individualism was one of the main topics of the Chicago school: only to mention the unadjusted girl, the Hobo, or the "marginal man." For W. I. Thomas, for example, exactly this constant infighting was the object of sociological investigation:

There is, of course, no pre-existing harmony whatsoever between the individual and the social factors of personal evolution, and the fundamental tendencies of the individual are always in some disaccordance with the fundamental tendencies of social control. Personal evolution is always a struggle between the individual and society - a struggle for self-expression on the part of the individual, for his subjection on the part of society. (Thomas 1951: 164, written 1918)

Now if a theory is overly intersubjectivist, it looses sight of this very fact; and with this, it ceases to be a critical theory (Whitebook 2001). This is the second crucial difference between pragmatism and Chicago sociology: for the latter, individuals are social entities who also have their own, partly anti-social drives; for pragmatists and neopragmatist social philosophers, however, everything is "always already" intersubjective - or at least it should be. This makes these theories rather smooth. ${ }^{30}$ Whereas the sociologist Albion Small stated: "All social factors are combinations of individual facts" (Small 1905: 3), the philosopher G.H. Mead argued against Small's fundamental "interests." They were which comes as no surprise - not social enough (Small 1905: 472). To Mead, even individual desires were socially constituted. However, this uplifting sociality was a philosophical idea, not social reality as experienced by normal people and investigated by the social sciences. Where Mead mentioned society, he talked about an "ideal" that resembled spiritual community; and the "Great Community" Dewey invoked was wishful thinking, at best. Not without irony, therefore, could the cultural critic John Patrick Diggins claim that even in modern American literature there was more social knowledge then in this 'sociological imagination': ${ }^{31}$

One can read almost the whole corpus of the literature of the 'lost generation' as a countercurrent to modern sociology. 'Primary group' associations hardly seemed nurturing to Sinclair Lewis, Sherwood Anderson, and other novelists in flight from small-town life; technology and organization, the inventions of the modern industrial age that Cooley looked to to revitalize 'face to face' relationships, led John Dos Passos to depict in the very structure of his narration the facelessness and homelessness of the modern condition. (Diggins 1994: 377)

Even conservative Diggins was troubled by the loss of critical perspective that came as a price for Dewey's premature conceptual reconciliation:

Dewey used the institution of 'marriage' as an example of how 'union' with others brings new levels of awareness and responsibilities. A curious example. Contemporary playrights like Eugene O'Neill saw the family as a sick institution of mendacious dialogues, repressed thoughts, ironic confrontations, hidden meanings, 
and neurotic personalitie. [...] And where Henry Adams had traced the disintegration of unifying principles to the eclipse of classical values at the birth of the republic, Dewey claimed that 'American democratic polity was developed out of genuine community life.' (Diggins 1994: 300f., citing Dewey LW 2: 304)

The real irony is that while Dewey and Mead saw social interaction as the answer to private individualism, Scottish philosophers saw the social self as the basis for the rise of modern capitalism. [...] Dewey believed that pragmatism had extirpated dualism for good, dissolved into social relations every absolute, and demonstrated how truth can be made and values created when desire experiences satisfaction. So did capitalism. (Diggins 1994: 379)

Not by change did Diggins (1994: 381) invoke Lionel Trillings Opposing Self: "that one may live a real life apart from the group, that one may exist as an actual person not only at the center of society but on its margings" (Trilling 1956: 107) - this was at risk in an overinclusive intersubjectivism. So the conceptual strategy proves to have a tremendous impact. Ironically, besides departing pragmatism from contemporary sociology, it also broke with the pragmatic creed when it came to politics. As discussed above, the road of reform was a "third way" between revolutionary and conservative strategies. If taken by heart, a pragmatic politics could only test by "experiment" which strategy would work best. Mead and Dewey, however, stopped short of this when it came to politics:

the limits the Chicago pragmatists put on social reconstruction belied the democratic principles they simultaneously espoused [...]. The Chicago philosophers advocated self-expression but believed it should follow a gradually progressive evolution from less to more rational social organization. If radical impulse played an increasingly important role, it did so within the confines of conservative habit and constructive working hypothesis. (Feffer 1993: 180)

60 Joas directs a similar criticism at Mead himself: where Mead talks about society and politics, he ceases to be a pragmatist and comes up with "utopian" notions how people should behave in society, regardless of context (Joas 1980: 207f.). This leaves us with the irony that even G.H. Mead, the master-thinker for the "sociological pragmatism" developed by Juergen Habermas, Axel Honneth and Hans Joas himself, was neither sociological nor pragmatistic enough. Something similar may be claimed for Dewey..$^{32}$ Even in Thomas' typology of the Bohemian, the Philistine and the creative man it is clear from the start 'who wins': the creative man, role model for the piecemeal-approach of progressive reformism, is of course superior to the blind revolutionary furore and the phlegmatic conservatism (Thomas 1951: 161, written 1918; cf. MW 14: 156).

61 The aim of this paper was to show the common ground between pragmatism and social theory. Hence, I do not want to overstress these differences. The philosophy of Dewey still has a lot to offer, especially when it is read in a way that transcends the historical context. An "opposing self" which neither finds support in a current culture, nor in given types of subjectivity, may still find normative resources in referring to its own nature, as described in Dewey's philosophy. This naturalistic non-conformism may also be found in Mead, Thomas, or Park. Therefore, my suggestion is that the next round of re-reading pragmatism (including the Chicago School) will have to rediscover another dimension beneath the topics of contingency and intersubjectivity: namely their moral perfectionism, the sophisticated ethical anthropology. Especially normative theories of recognition have read Dewey too much as a conformist. ${ }^{33}$ In part, this is a correct representation of what is there in Dewey. But in part it is also an unnecessarily purificatory reading. 


\section{Outlook: Pragmatism and Critical Theory On Politics}

62 are necessarily post-foundational. It would be a misreading that pragmatism only has to offer an experimental method and a situationist ethics (let's see what helps best in every single case). There is much more to discover. Dewey, in particular, should be read as a 'Critical theorist' of his own kind. Especially with the stress on habits, already prominent in both Hume and James (1890), but essentially an Aristotelian ethical term, progressivist writers developed an early exponent of modern perfectionism or Neo-Aristotelianism as later articulated in Martha Nussbaum and others. Following Derek Parfit, today those theories are called "objective list" theories of happiness. In the social forces-approach of Ward, Small, and Thomas we indeed found such objective lists. Consequently, progressivist social theory needs to be reconstructed neither from a Darwinian nor from a Kantian, but from an Aristotelian perspective (Chugerman 1939; Henning 2010).

63

However, the link of pragmatism to politics seems to be a complicated issue, so will touch it one more time. We have seen that Dewey's and Mead's politics were not fully in line with their philosophy. Joas attributed this to an inconsistent translation into sociology. ${ }^{34}$ The social theory of the day itself had, or so I argued, developed a more consistent way of allowing for naturalistic arguments in social theory. However, due to their professionalization they ceased to forge bridges to politics; leaving it to politicians to draw the conclusions. How to get from naturalistic values to progressive politics remains an open question. Would they have lead to a different political agenda, with more experimentalism in politics? Consider Dewey's relation to socialism. Karl Marx had developed a radical political theory that was based not only on his economic theory, but also on naturalistic values quite similar to the ones guiding progressivism; only to mention the ethos of self-realization by way of creative activity or the communal selfgovernance, including "industrial democracy"; a goal Dewey and Mead basically shared (fn. 7). Why, then, did pragmatists not embrace Socialism (as one of the main "European social theories") more openly?

Applying pragmatism to this question gives a surprising answer: it was not due a difference in principle, for neither pragmatism nor Marxism dealt with principles that much. In fact, both schools aimed to think in a more mundane way, analyzing facts and guiding action without descending into scholastic debates. The answer rather lies in the situation. In the late 1930s, the situation of the day, especially within the leftist New York intellectual scene, was already one of a growing - but painful - disentanglement from Stalins Russia in the 1930s. Nevertheless, Frankfurt School theorists attacked pragmatism as "positivistic," again implying that it was not political and 'social enough.' Either this contextualization had completely escaped the Horkheimer circle (as had the debates about Hegel, Marx, and Lenin between Eastman and Hook), ${ }^{35}$ or their own "political alignment" was very questionable, as Joas (1992: 104) implies. So in retrospective Sidney Hook ("Dewey's bulldog," who rushed to defend pragmatism) has clearly won this encounter. His strong link of science and practice allowed him a clear stand not only in theory, but also in politics; e.g. towards communism - a topic avoided by Critical theory for a long time. Hook was aiming at a social theory both critical and pragmatic. He had already lost his Hegelian spillovers due to an earlier encounter with Max Eastman, another former student of Dewey. For years Eastman and Hook had quarreled in public 
about the proper way to apply pragmatism to Marxism, and both of them to politics. Both had tried to draw Dewey into Marxism, without much success (at least, he helped defending Trotzky). Ironically, both of them became decisive Cold War-Anticommunists some years later. In any case, this confrontation between two of the most influential schools of social theory - pragmatism and Critical Theory - has certainly not contributed to solving the question how natural values could be applied to politics. ${ }^{36}$ It could only be answered with respect to a concrete situation.

Therefore, this questions remains to be asked today. It is no coincidence that many of the progressive topics resurface today - human sympathy in the new moral sentimentalism, the larger mind in phenomenological theories of we-intentionality, and progress in the efforts to 'direct' an unregulated global capitalism. Currently evolutionary psychologists again argue in favor of empathy and cooperation, against ideologies trying to naturalize the market egoism of contemporary capitalism (Tomasello 2009, de Waal 2010). The suggestion I made in this article is that in order to ask these questions anew, it is desirable to reconsider the theory of naturalistic values implicit in the progressive movement, including Dewey, but also including American sociologists preceding the Chicago school. Many arguments pragmatists have made can be found there already, in a way that was less sophisticated, but more open to real life situations than Dewey and Mead were in some of their writings

\section{BIBLIOGRAPHY}

ALLERFELDT K. (ed.), (2007), The Progressive Era in the USA: 1890-1921, Aldershot, Ashgate.

BARNES H. E. (ed.), (1948), An Introduction to the History of Sociology, Chicago, University of Chicago Press.

BERNARD L., (1924), Instinct. A Study in Social Psychology, New York, Holt.

BOHMAN J., (2010), "Ethics as Moral Inquiry: Dewey and the Moral Psychology of Social Reform," in Cochran M. (ed.), Cambridge Companion to Dewey, Cambridge, Cambridge University Press.

BURGESS E. W. \& R. E. PARK (eds.), (1921), Introduction to Science of the Sociology, Chicago, University of Chicago Press.

CHUGERMAn S., (1939), Lester F. Ward: The American Aristotle, Durham, Duke University Press. COHEN N., (2002), The Reconstruction of American Liberalism, Chapel Hill, University of North Carolina Press.

COOLEY C. H., (1902), Human Nature and the Social Order, New York, Scribner. COOLEY C. H, (1909), Social Organization. A Study of the Larger Mind, New York, Charles Scribner's Sons.

COSER L. A., (1971), Master of Sociological Thought, New York, Harcourt. 
DAHMS H. J., (1994), Positivismusstreit. Die Auseinandersetzungen der Frankfurt Schule mit dem logischen Positivismus, dem amerikanischen Pragmatismus und dem kritischen Rationalismus, Frankfurt, Suhrkamp.

DE WAAL F., (2010), The Age of Empathy. Nature's Lessons for a Kinder Society, New York, Three Rivers. DEWEY J., (1888), “The Ethics of Democracy,” The Early Works of J. Dewey, 1982-1898, vol. 1 (EW 1), ed. by J. A. Boydston, Southern Illinois University Press, Carbondale and Edwardsville 1969.

DEWEY J., (1894), "Review of F. L. Ward, The Psychic Factors of Civilization," The Early Works of J. Dewey, 1982-1898, vol. 4 (EW 4), ed. by J. A. Boydston, Southern Illinois University Press, Carbondale and Edwardsville 1971.

DEWEY J., (1916), Democracy and Education. An Introduction to the Philosophy of Education, The Middle Works of J. Dewey, 1899-1924, vol. 9 (MW 9), ed. by J. A. Boydston, Southern Illinois University Press, Carbondale and Edwardsville 1980.

DEWEY J., (1920), Reconstruction in Philosophy, The Middle Works of J. Dewey, 1899-1924, vol. 12 (MW 12), ed. by J. A. Boydston, Southern Illinois University Press, Carbondale and Edwardsville 1982.

DEWEY J., (1922), Human Nature and Conduct, The Middle Works of J. Dewey, 1899-1924, vol. 14 (MW 14), ed. by J. A. Boydston, Southern Illinois University Press, Carbondale and Edwardsville 1983.

DEWEY J., (1925), Experience and Nature, The Later Works of J. Dewey, 1925-53, vol. 1 (LW 1), ed. by J. A. Boydston, Southern Illinois University Press, Carbondale and Edwardsville 1983.

DEWEY J., (1935), Liberalism and Social Action, The Later Works of J. Dewey, 1925-53, vol. 11 (LW 11), ed. by J. A. Boydston, Southern Illinois University Press, Carbondale and Edwardsville 1987.

DEWEY J., (1943), “Anti-Naturalism in Extremis,” The Later Works of J. Dewey, 1925-53, vol. 15 (LW 15), ed. by J. A. Boydston, Southern Illinois University Press, Carbondale and Edwardsville 1989.

DEWEY J. \& J. TUFT (1908), Ethics, The Middle Works of J. Dewey, 1899-1924, vol. 5 (MW 5), ed. by J. A. Boydston, Southern Illinois University Press, Carbondale and Edwardsville 1978.

DIGGINS P., (1975), Up From Communism. Conservative Odysseys in American Intellectual Development, New York, Columbia University Press.

DIGGINS P., (1992), The Rise and Fall of the American Left, New York, Norton.

DIGGINS P., (1994), The Promise of Pragmatism. Modernism and the Crisis of Knowledge and Authority, Chicago, University of Chicago Press.

DIGGINS P., (2005), "Sidney Hook, Robert Nozick, and the Paradox of Freedom," Social Philosophy and Policy 22, 200-20.

EISENACH E. J., (1994), The Lost Promise of Progressivism, University Press of Kansas.

FARIS E., (1921), “Are Instincts Data or Hypotheses?,” in Faris E. (1937), The Nature of Human Nature, New York, McGraw.

FEFFER A., (1993), The Chicago Pragmatists and American Progressivism, Ithaca, Cornell University Press.

GALE R. M., (2010), “The Naturalism of John Dewey,” in M. Cochran (ed.), The Cambridge Companion to Dewey, Cambridge, Cambridge University Press, 55-79.

GREEN T. H., (1881), "Lecture on Liberal Legislation and Freedom of Contract," in Works III, New York 1969. 
HENNING C., (2009), "Karl Marx," in Bohlken E. \& Thies C. (eds.), Handbuch Anthropologie. Der Mensch zwischen Natur, Kultur und Technik, Stuttgart, Metzler.

HENNING C., (2010), "Natur und Freiheit im Perfektionismus: Zum Verständnis der Natur des Menschen in progressiven Traditionen," Deutsche Zeitschrift für Philosophie 5/2010.

HOFSTADTER R., (1955), The Age of Reform: From Bryan to F.D.R., New York, Knopf.

HONNETH A., (2000), “Zwischen Prozeduralismus und Teleologie: Ein ungelöster Konflikt in der Moraltheorie von John Dewey," in Joas H. (ed.), Philosophie der Demokratie: Beiträge zum Werk von John Dewey, Frankfurt, Suhrkamp.

HORNEY K, (1937), The Neurotic Personality of Our Time, New York, Norton.

JAMES W., (1890), Principles of Psychology, 2 Vls., Reprint 2007, New York, Cosimo.

JOAS H., (1980), Praktische Intersubjektivität. Die Entwicklung des Werks von G. H. Mead, Frankfurt, Suhrkamp.

JOAS H., (1992), Pragmatismus und Gesellschaftstheorie, Frankfurt, Suhrkamp.

KLOPPENBERG J., (1986), Uncertain Victory: Social Democracy and Progressivism in European and American Thought 1870-1920, Oxford, Oxford University Press.

KROPOTKIN P., (1902), Mutual Aid: A Factor of Evolution, London, Heinemann.

LEPENIES W., (1985), Between Literature and Science. The Rise of Sociology, Cambridge, Cambridge University Press.

LEWIS J. \& R. SMITH, (1980), American Sociology and Pragmatism: Mead, Chicago Sociology, and Symbolic Interaction, Chicago, Chicago University Press.

LINDNER R., (1996), The Reportage of Urban Culture. Robert Park and the Chicago School, Cambridge, Cambridge University Press.

LINDNER R., (2000), “Robert Ezra Park,” in Kaesler D. (ed.), Klassiker der Soziologie, München, Beck. MANICAS P., (2008), Rescuing Dewey. Essays in Pragmatic Naturalism, Lanham, Lexington Books. MEAD G. H., (1930), “Cooley's Contribution to American Social Thought," American Journal of Sociology 35, 693-706.

MEAD G. H., (1934), Mind, Self, and Society from the Standpoint of a Social Behaviorist, Chicago, University of Chicago Press.

odin S., (1996), The Social Self in Zen and American Pragmatism, Albany, State University of New York Press.

PARK R. E., (1915), “The City: Suggestions for the Investigation of Human Behavior in the City Environment," American Journal of Sociology 20, 579-83.

PARK R. E. et al., (1925), The City: Suggestions for the Study of Human Nature in the Urban Environment, Chicago, University of Chicago Press

PARK R. E., (1967), On Social Control and Collective Behavior, R. Turner (ed.), Chicago, University of Chicago Press.

PINKER S. (2002), The Blank Slate: The Modern Denial of Human Nature, New York, Penguin.

PHELPS C., (1997), Young Sidney Hook. Marxist and Pragmatist, Ithaca, Cornell University Press. 
PRIER S., (2008), “A Peirceian Panentheist Scientific Mysticism," Journal of Transpersonal Studies 27, 20-45

RAFFERTY E. C., (2003), Apostle of Human Progress: Lester Frank Ward and American Political Thought, 1841-1913, Lanham, Rowman \& Littlefield

RORTY R., (1977), “Dewey’s Metaphysics," in Cahn S. (ed.), New Studies in the Philosophy of John Dewey , Lebonon, NH, University Press of New England.

Ross D., (1991), The Origins of American Social Science, Cambridge, Cambridge University Press.

Ross E. A., (1901), Social Control, New York, MacMillan.

SALomon G., (1926), "Die organische Staats- und Gesellschaftslehre," in Salomon G. \& Delatour G. (2012), Schriften, ed. C. Henning, Wiesbaden, VS.

SANDEL M., (1996), Democracy's Discontent: America in Search of a Public Philosophy, Cambridge, MA, Harvard University Press.

SCHUBERT H. J, (1995), Demokratische Identität. Der soziologische Pragmatismus von Charles Horton Cooley, Frankfurt, Suhrkamp.

SCHUBERT H. J. et al., (2010), Pragmatismus zur Einführung, Hamburg, Junius.

SHALIN D. N., (2011), Pragmatism and Democracy. Studies in History, Social Theory, and Progressive Politics, New Brunswick, Transaction.

SMALl A. W., (1905), General Sociology, Chicago, University of Chicago Press.

SMALl A. W., (1910), The Meaning of Social Science, Chicago, University of Chicago Press.

SMALl A. W., (1916), "Fifty Years of Sociology in the United States (1865-1915)," American Journal of Sociology, XXI.6, 721-864.

STAMMLER R, (1896), Wirtschaft und Recht nach der materialistischen Geschichtsauffassung, Leipzig, Veit.

SUMNER W. G., (1883), What Social Classes owe to Each Other, New York, Harper.

SUMNER W. G., (1907), Folkways: A Study of the Sociological Importance of Usages, Manners, Customs, Mores, and Morals, Boston, Ginn.

SUMNER W. G., (1914), The Challenge of Fact and other Essays, New Haven, Yale University Press.

TENBRUCK F., (1985), “George Herbert Mead und die Ursprünge der Soziologie in Deutschland und Amerika," in Joas H. (ed.), Das Problem der Intersubjektivität: Neuere Beiträge zum Werk von George Herbert Mead, Frankfurt, Suhrkamp.

THOMAS W. I. \& F. ZNANIECKI, (1918-20), The Polish Peasant in Europe and America: Monograph of an Immigrant Group, 5 Vls., Boston, Badger.

THOMAS W. I., (1921), Old World Traits transplanted, New York, Harper.

THOMAS W. I., (1951), Social Behaviour and Personality, Westport, Greenwood.

TOMASEllo M., (2009), Why we cooperate, Cambridge, Mass., MIT Press.

TRILLING L, (1956), A Gathering of Fugitives, Boston, Beacon Press.

WARD F. L., (1883), Dynamic Sociology, 2 Vls., New York, Appleton.

WARD F. L., (1893), The Psychic Factors of Civilization, Boston, Glinn 
WARD F. L., (1897), Outlines of Sociology, New York, MacMillan.

WARD F. L., (1903), Pure Sociology. A Treatise on the Origin and Spontaneous Development of Society, New York, MacMillan.

WARD F. L., (1918), Glimpses of the Cosmos, New York, Putnam.

WHEATLAND Th., (2009), The Frankfurt School in Exile, Minneapolis, University of Minnesota Press.

шнітевоок J., (2001), "Mutual Recognition and the Work of the Negative," in Rehg W. \& Bohman J. (eds.), Pluralism and the Pragmatic Turn. The Transformation of Critical Theory, Cambridge MA, MIT

Press.

WRIGHT MILLS C., (1964), Sociology and Pragmatism. The Higher Learning in America. (Dissertation from 1941), New York, Oxford University Press.

\section{NOTES}

1. Park 1915, Thomas \& Znaniecki 1918-20, Burgess \& Park 1921, Thomas 1921.

2. Cooley, Journal XXII, 1921, cited from Odin (1996: 162), also cited in Joas (1992: 33).

3. Lewis \& Smith (1980: 167). They also describe pragmatism's impact on W. I. Thomas and Herbert Blumer.

4. Odin (1996: 162), as in note 2.

5. For Cooley's verdict on Spencer see Coser (1971: 319). For Joas Mead remains a sociological champion. Lewis \& Smith 1980 made the stronger claim that Mead is no sociologist at all: he was interested in ethics and empirical psychology, but has never conducted sociological research or taught sociology (the same is true for Dewey, Peirce and James).

6. See Eisenach (1994, 138ff.), and Cohen (2002, 143ff.).

7. Concerning the "supposed tendency of democracy toward socialism, if not communism," Dewey proclaimed: "there is not need to beat around the bush in saying that democracy is not in reality what it is in name until it is industrial" (EW 1: 246; see Feffer 1993: 142ff.). For Mead's position on "socialism"; see Shalin (2011: 37ff., 51f.).

8. On Sumner see D. Ross (1991: 85ff.); Cohen (2002: 148ff.).

9. Lindner (2000: 215); cf. Coser (1971: 368f.).

10. See Barnes (1948: 173ff.), Hofstadter (1955: 67ff.); D. Ross (1991: 88ff.); Rafferty 2003.

11. Ward (1883 I: 60); cf. Chugerman (1939: 319ff.).

12. Mead in a letter from 1890 , cited in Shalin $(2011,46)$. As many will remember, Lenin was impressed, too; especially by the German post office.

13. Cf. Cooley (1902: 136ff.); E. A. Ross (1901: 7ff.); and Kropotkin 1902.

14. See Lewis \& Smith (1980: 155ff.); Schubert (2010: 80ff.).

15. The "health interest" is subdivided into "Food," "Sex" and "Work interest."

16. Ward (1918 VI: 337), cf. Chugerman (1939: 439).

17. Schubert (2010: 81) sees an influence of Peirce here: creative action is not necessarily a response to an external problem, but may also result from a desire for play or creation.

18. Thomas (1951: 111-44) documents versions of this theory from 1917 to 1925. Park \& Burgess (1921: 435-504) have a long chapter about "social forces," with many authors.

19. Green 1881; Ward (1883 II: 233: liberty is "the power to act"); Cooley (1902: 433ff.).

20. This is a parallel to German "philosophical anthropology" of the 1920s, which also maintained that there is a human nature, but it neither determines nor predicts human behavior. 21. Dewey clearly acknowledged his Darwinian influences several times. In the foreword to Human Nature and Conduct from 1930, he also endorsed Hume (see Bohman 2010: 191). 
22. For Rorty 1977, Dewey's naturalism was a lapse. In German political philosophy this interpretation is still relevant (Honneth 2000).

23. Put traditionally: Ultra posse nemo obligatur.

24. Whereas Dewey traveled to China, Japan, Turkey, and Russia, members of the Chicago school (Thomas, Park, and Faris, e.g.) later turned to migration and so-called "race relations" in the USA in order to promote some progress there.

25. Apart from commenting on pragmatists, neither are they pragmatistic (which is not a shame, no one has to be): their philosophy does not analyze concrete situations, but aims at general theories and highly abstract concepts like communicative action, recognition, or value.

26. "One thing Dewey accomplished through his reconstruction of psychological terminology was to claim the mantle of science for a philosophical tradition in danger of being closed out of the experimental laboratory" (Feffer 1993: 149f.).

27. Peirce and James were open to mysticism, too (Prier 2008).

28. To quote the order of chapters in Burgess \& Park 1921, cf. Coser (1971: 359f.).

29. To readers of Walter Benjamin this sounds familiar. Probably the link is Wilhelm Windelband, with whom Park wrote his Dissertation in 1905.

30. Axel Honneths latest book from 2011 is an example for this tendency.

31. For the relationship of literature to sociology see Lepenies 1985.

32. For Diggins 2005, Dewey ceased to be a pragmatist when it came to democracy: It was no longer an "end in view" that could be falsified by future experience; it was as firmly based and deeply rooted in human life as anything has ever been in traditional philosophy.

33. A wish for recognition was already present in Thomas' four wishes, but only as one among many. Since it is based on social distinction, it has rather anti-social effects (sometimes bordering on neurosis, see Horney 1937). So looking back at these debates may help contemporary theory to resharpen its critical teeth.

34. Remember that Karl Marx had claimed philosophy needed to be overturned (into science) and realized (into practice; the German terms are "aufheben" and "verwirklichen").

35. Hooks debates with Eastman are described by Diggins (1975: 51ff.; 1992: 158ff.) and Phelps (1997: 38ff., 96ff.); Hooks encounter with Horkheimer by Dahms (1994: 191ff.) and Wheatland (2009: 97ff.).

36. Despite obvious parallels, especially between Marcuse and Dewey. Marcuse had actually read Dewey and even contributed some reviews (see Dahms 1994).

\section{ABSTRACTS}

The paper argues that Dewey's ethics are based on a naturalistic theory of value. This unusual interpretation questions the anti-naturalist reading of Dewey in the wake of Richard Rorty and other neo-pragmatists. In order to defend this interpretation, I develop a genealogy of Dewey's pragmatic naturalism: It has a 'father' in the progressivist movement, and a 'sister' in the Chicago Sociology. A closer look at Frank L. Ward, Albion Small, W. I. Thomas and Robert Park helps to reconstruct the political dynamics of the progressivist programme of naturalistic values. This contextualization may also correct some of the shortcomings of Dewey's own version: Some pragmatic sociologists spelled out the noncomformist individualism more clearly than Dewey's philosophy did. Finally I suggest that this approach is still relevant today. 


\section{AUTHOR}

\section{CHRISTOPH HENNING}

University of St. Gallen - Switzerland

christoph.henning[at]unisg.ch 